\title{
Research Is an Activity and a Subject of Study: A Proposed Metaconcept and Its Practical Application
}

\section{Allison Hosier}

\begin{abstract}
Information literacy instruction based on the ACRL Information Literacy Competency Standards for Higher Education tends to focus on basic research skills. However, research is not just a skill but also a subject of study. The ACRL Framework for Information Literacy for Higher Education opens the door to integrating the study of research into information literacy instruction via its acknowledgement of the contextual nature of research. This article introduces the metaconcept that research is both an activity and a subject of study. The application of this metaconcept in core LIS literature is discussed and a model for incorporating the study of research into information literacy instruction is suggested.
\end{abstract}

\section{Introduction}

Studies have shown that students' confidence in their research skills often does not match their proficiency with those skills. ${ }^{1}$ Students seem to believe that their facility with search engines is sufficient for any research-related task they may be faced with. In believing this, what students fail to realize is that while the information-seeking skills they have developed are certainly valuable in some situations, they are less so in others.

Instructors of composition courses face a similar dilemma. Students believe that writing is nothing more than a basic skill and often fail to appreciate the importance of rhetorical context to the writing process. In an effort to resolve this, instructors help students familiarize themselves with different genres of writing via the study of writing itself. As a result, students may begin to recognize that basic skills are not enough to meet the expectations for writing in every context. The most successful student writers are ones who are able to recognize themselves as novices in some of these contexts. ${ }^{2}$ These student writers will also begin to see that writing is not just an activity but also a subject of study. ${ }^{3}$

Students who learn about research through information literacy instruction may not have the opportunity to experience a similar epiphany about the research process. This is because common models of information literacy instruction are primarily skills-based with a particular focus on application. There is little if any time to devote to teaching students about the contextual nature of research or how to study a research product for evidence of conventions related to these contexts.

\footnotetext{
*Allison Hosier is Information Literacy Librarian in the University Libraries at the University at Albany, State University of New York; email: ahosier@albany.edu. (02019 Allison Hosier, Attribution-NonCommercial (http:// creativecommons.org/licenses/by-nc/4.0/) CC BY-NC.
} 
If information literacy instruction is typically skills-based, it is likely because the ACRL Information Literacy Competency Standards for Higher Education (the Standards) is a skills-based document, as are similar documents that have shaped how information literacy has been taught until now. The Standards guidelines in particular fail to address the contextual nature of research in a meaningful way, thus limiting opportunities to introduce this important concept in the classroom.

The advent of the ACRL Framework for Information Literacy for Higher Education (the Framework) marks a shift from skills-based thinking about information literacy to concept-based thinking. Because of this shift, information literacy instructors now have the option to expand their teaching beyond the application of basic research skills. The Framework's attention to context in particular can be used to create a model of instruction that involves the study of research in addition to the application of research skills. In this way, students will better recognize that research, like writing, is both an activity and a subject of study.

The purpose of this article is threefold. The first is to propose the metaconcept that research is both an activity and a subject of study. This metaconcept has long been present in the literature in the library and information science field but has been largely absent from information literacy instruction. The second goal of this study is to discuss how the influence of the Standards led to the skills-based model of information literacy instruction while suggesting that the Framework's attention to context provides a path for reshaping such instruction around the study of research. Third, a model for integrating this metaconcept into information literacy instruction will be presented.

These ideas were initially inspired by Adler-Kassner and Wardle's edited volume Naming What We Know: Threshold Concepts of Writing Studies. Just as Adler-Kassner and Wardle and their collaborators aimed to articulate what writing studies experts know about their subject to improve conversations with students and other nonexperts, the application of the ideas in the present study can lead to better discussions about information literacy with those who in the past may not have fully understood its value.

\section{Defining Research}

Before getting to the heart of this paper's argument, it may be helpful to first establish more clearly what, exactly, is meant by "research."

In their "Policy for Protection of Human Research Subjects," the Office for Human Research Protections defines research as a systematic investigation intended to contribute to generalizable knowledge. ${ }^{4}$ Institutional Review Boards commonly use this definition to guide researchers applying for approval to pursue research involving human subjects.

The Standards also portrays research as an investigation, one that likely involves the use of library resources. The prescribed steps for the research process include the identification of a gap in knowledge, the identification and evaluation of relevant sources, and the ethical use of those sources. ${ }^{5}$

In the Framework, research is alluded to as a "reflective discovery of information" in the expanded definition of information literacy. ${ }^{6}$ This journey of reflective discovery is intended to lead to the creation of new knowledge.

Information-seeking is a concept related closely to research that takes into consideration contexts beyond the scientific and academic ones that are the primary concern of the above definitions. Wilson describes information-seeking as a behavior that "arises as a consequence 
of a need perceived by an information user who...makes demands upon formal or informal information sources or services, which result in success or failure to find relevant information." 7

It is necessary to define research broadly in a discussion of research as both an activity and a subject of study, because the study of research can take many forms and context is always a consideration. For this reason, the understanding of research in this paper will encompass the following:

- Research is any formal or informal process that is undertaken to fill a gap in knowledge, build on existing knowledge, or create new knowledge.

- Goals of research include but are not limited to answering a research question, testing a hypothesis, or satisfying curiosity.

- Research involves investigation of some kind. This investigation may be formal, such as an exhaustive literature review or the careful implementation of the scientific method, or it may be informal, such as a brief Google search. More formal research investigations may be qualitative or quantitative in nature.

- The research process is often iterative rather than linear.

- The results of research may be captured in a research product or a set of research products. The products of research can take many forms, including but not limited to: formally published research studies, dissertations, conference proceedings, creative works, presentations, speeches, news and magazine articles, and blog posts.

- Research products often include evidence of research in some way, whether it is a list of citations, a detailed description of methodology, a quote from an interview subject, a list of acknowledgements, a verbal allusion to a source of information (as in a speech), or contextual links (as in an online blog post).

\begin{tabular}{|l|l|l|l|}
\hline \multicolumn{5}{|c|}{ Outline of Types of Research } \\
\hline $\begin{array}{l}\text { Type of } \\
\text { Research }\end{array}$ & Description & $\begin{array}{l}\text { Example Research } \\
\text { Products }\end{array}$ & $\begin{array}{l}\text { Example Evidence of } \\
\text { Research }\end{array}$ \\
\hline $\begin{array}{l}\text { Academic } \\
\text { Research }\end{array}$ & $\begin{array}{l}\text { Most often performed by professors and } \\
\text { students in academic environments. Often } \\
\text { involves the use of library resources but } \\
\text { not always. May be disciplinary in nature. }\end{array}$ & $\begin{array}{l}\text { Scholarly articles, } \\
\text { research papers, } \\
\text { dissertations, } \\
\text { theses }\end{array}$ & $\begin{array}{l}\text { Detailed literature } \\
\text { reviews and citations }\end{array}$ \\
\hline $\begin{array}{l}\text { Creative } \\
\text { Research }\end{array}$ & $\begin{array}{l}\text { Performed as part of the process of } \\
\text { producing a creative work }\end{array}$ & $\begin{array}{l}\text { Novels, popular } \\
\text { nonfiction, a } \\
\text { performance }\end{array}$ & $\begin{array}{l}\text { Notes on sources; lists of } \\
\text { acknowledgements and } \\
\text { credits }\end{array}$ \\
\hline $\begin{array}{l}\text { Personal } \\
\text { Research }\end{array}$ & $\begin{array}{l}\text { Undertaken to satisfy a personal } \\
\text { information need or to satisfy curiosity }\end{array}$ & $\begin{array}{l}\text { Social media posts, } \\
\text { blog entries }\end{array}$ & $\begin{array}{l}\text { Contextual links, informal } \\
\text { notes on sources used (if } \\
\text { any) }\end{array}$ \\
\hline $\begin{array}{l}\text { Professional } \\
\text { Research }\end{array}$ & $\begin{array}{l}\text { Required as part of a job in a particular } \\
\text { field }\end{array}$ & $\begin{array}{l}\text { News articles, } \\
\text { presentations, } \\
\text { reports, memos }\end{array}$ & $\begin{array}{l}\text { Quotes from interview } \\
\text { subjects, brief citations } \\
\text { (formal or informal) to } \\
\text { sources }\end{array}$ \\
\hline $\begin{array}{l}\text { Scientific } \\
\text { Research }\end{array}$ & Follows the scientific method & $\begin{array}{l}\text { Peer-reviewed } \\
\text { articles, research } \\
\text { studies and reports }\end{array}$ & $\begin{array}{l}\text { Cited sources, detailed } \\
\text { descriptions of } \\
\text { methodology }\end{array}$ \\
\hline
\end{tabular}


Research envisioned through an information literacy lens is often academic in nature. This type of research will be referred to as "academic research" throughout this paper. Table 1 outlines additional terms that will be used to refer to different types of research where necessary. This is not intended as a definitive list of research genres but rather a guide that will serve to clarify certain points. Note that some types of research may overlap with others.

\section{Research Is a Subject of Study}

A study of research is one in which the products or processes of research are analyzed to better understand some aspect of research itself. This is most directly seen in studies that observe actual research behaviors or evaluate specific research products. The study of research also has an influence on other areas of inquiry. Context is often key to studies of research.

The study of research is most prevalent in literature found in the library and information science (LIS) field. However, it also has relevant applications in other fields. This section will first summarize areas of inquiry directly and indirectly related to the study of research that can be found in LIS literature. A few relevant examples from the related field of writing studies will also be mentioned. Brief consideration will then be given to a relevant example from the field of psychology.

\section{The Study of Research in Library and Information Science}

Researchers in library and information science study the processes and products of research to improve systems and services, to understand how those systems and services are used, to analyze collections, to measure the impact of research-related instruction, to trace the development of a research topic over time, and more. These areas of inquiry are studied in a variety of contexts using a range of methods and populations. The study of research is relevant to virtually every specialization in library and information science. It is not an exaggeration to say that if you open any of the core journals in this field, such as those identified in a 2014 study by Nixon, ${ }^{8}$ you are likely to find at least one article that is concerned directly or indirectly with the study of research in some way, shape, or form.

The study of research is a theme that has long been present in LIS literature but can be difficult to locate because until now it has not generally been named as such. The metaconcept introduced here gives us a novel lens through which to view our work and begin to articulate what we know about research as both an activity and a subject of study in a new way. When this lens is applied to content analyses and literature reviews, which are fairly common in LIS literature ${ }^{9}$ and are themselves an example of the study of research, these works can serve as a valuable proxy for identifying topics related to the study of research in our field. An analysis by Tuomaala, Jarvelin, \& Vakkari from 2014 may be most useful in this respect for the present discussion. ${ }^{10}$ The breakdown of topics and subtopics the authors created for their study is specific enough to begin to see shades of the research-as-subject metaconcept. In their analysis, the authors found that information seeking, which includes subtopics such as information use and information management, accounted for 12.3 percent of the LIS literature in 2005, the most recent year considered for the study. The study of research also has applications related to studies of information storage and retrieval, a separate topic that includes subtopics such as cataloging and the testing of retrieval systems. More than 30 percent of the articles published that year related to this topic. Other potentially relevant areas from Tuomaala, Jarvelin, and Vakkari's study include research on user education $(1.7 \%)$, citation patterns $(6.5 \%)$, and webometrics $(2.9 \%)$. 
What does the study of research in LIS look like? For one, it is often concerned with context. Researchers seek to gain important insights into how different populations seek or use information in different contexts. Some of the populations studied in recent issues of core LIS journals include disadvantaged adolescents, Catholic clergy, linguists, and poultry farmers, to name just a few. ${ }^{11}$ Contexts of interest found in recent literature include not just academic or scholarly ones ${ }^{12}$ but also personal, as in studies of everyday life information seeking, ${ }^{13}$ and professional, as in studies of how information is accessed and used in various workplace environments. ${ }^{14}$ Those who study the products of research may be interested in understanding how researchers cite data, what common themes can be found in the research on a particular subject, or how the content of one type of research product might distinguish it from another type of research product. ${ }^{15}$ In all of these cases, context matters to the researcher.

Context also matters to those whose work may be informed by the study of research though research itself is not the direct object of study. For example, the work of collection management researchers must be informed at least in part by how a particular population uses the collection in question. ${ }^{16}$ Usability studies may be primarily concerned with issues of design, but the researcher must also take into account the context in which the resource being tested will actually be used..$^{17}$ A study of a library's physical space must include some consideration for the research and information-seeking activities that users conduct in that space, which will be different depending on details such as the type and size of the library as well as the population it serves. ${ }^{18}$ Researchers who create algorithms or implement other methods to improve the effectiveness of information retrieval systems must have some understanding of the needs and behaviors of the system's front-end users. ${ }^{19}$ Though the examples cited are all from recent literature, they represent areas of inquiry that have developed over a long period of time.

In the past, the study of academic research as conducted by students has been of particular concern to those who teach information literacy. Leckie, for example, comments on how typical research assignments reflect an expert approach to research that may be inaccessible to novice student researchers. ${ }^{20}$ Information literacy instruction is also often informed by studies that establish an understanding of students' research behavior, including their method of strategic satisficing, ${ }^{21}$ why they prefer certain resources and tools over others, ${ }^{22}$ and why their choices do not always match expert expectations of quality and reliability. ${ }^{23}$ Understanding gaps between the research skills librarians teach and the ones that are actually used in the workplace, as in Head, Van Hoeck, Eschler, and Fullerton, is another area of inquiry that has gained importance over time. ${ }^{24}$

Among these studies of the products and processes of academic research are arguments for teaching students about the contextual nature of research. Fister advocates for creating a better awareness of the rhetorical aspects of research, ${ }^{25}$ an idea that was later put into action by Davidson and Crateau ${ }^{26}$ Simmons proposes applying genre theory and critical information literacy to research instruction so that librarians can position themselves as discourse mediators, studying and teaching the conventions of research in different disciplines as anthropologists study and teach the practices of different cultures. ${ }^{27}$ Harris makes a similar argument: "Before we make assumptions about how to assist communities of learning, we may also need to define and navigate the social, political, and cultural characteristics of that community." ${ }^{28}$

The study of research touches nearly every aspect of the library and information science field, in one form or another. But, as Faix points out, experts in other fields also take part in 
scholarly conversations about research..$^{29}$ This includes related fields such as writing studies, where authors like Brent and North approach the study of research from a composition perspective..$^{30}$ However, the study of research is also relevant to researchers in more scientific fields, which are often considered outside the scope of information literacy instruction. Though this paper focuses primarily on information literacy instruction, the overall argument is that such instruction would be more effective if it involved the study of research to help students appreciate the contextual nature of the research process. This means expanding our thinking about research beyond the library-based academic notions we have favored so far. For this reason, a relevant example of the study of research in psychology is provided in the next section.

\section{The Study of Replicability and Reproducibility in Psychology}

The methods, goals, and motivations of scientific research are considered to be distinct from the ones described by documents such as the Standards and the Framework. That this is the case serves as further evidence in support of the importance of context to the research process. However, scientific researchers have also been known to turn inward and examine the processes and products of research as it is represented in their fields.

In the field of psychology, the work done as part of the Reproducibility Project is particularly relevant to the present discussion. As part of this project, a team of researchers attempted to replicate the results of 100 psychological studies. ${ }^{31}$ Their findings led them to create a set of recommendations for how to improve the research and publication process in their field to better promote replicability. One of these recommendations was to teach students to study research publications in their fields to evaluate the evidence used and learn to see potential methodological flaws.

The findings of this project inspired a number of responses. Some researchers studied the methods undertaken by those who worked on the project and used these analyses to question or criticize the results. ${ }^{32}$ Others turned to conversations about whether replicability and reproducibility should be goals of psychological research in the first place. ${ }^{33}$ There are also studies, ${ }^{34}$ published since then, that seek to establish whether there are methods that can be used to improve the replicability of a study and others ${ }^{35}$ that recommend new approaches to evaluating replicability itself. A similar study to investigate the reproducibility of cancer biology research is also being undertaken. ${ }^{36}$

From these discussions, it becomes clear that research is not just an activity but also a subject of study for researchers in LIS and other fields. This metaconcept has important connections to the contextual nature of research. Both ideas are essential to learning about research in a meaningful way. Despite this, information literacy instruction tends to be generally skillsbased with little or no discussion of these ideas. The reason for this may be that, for many, models of information literacy instruction have been built around the Standards, a document that places priority on teaching research skills over research-related concepts.

\section{The Importance of Context: Limitations of the Standards and New Opportunities}

As stated earlier, the Standards is a skills-based document. When considering the historical context of this document, its focus on the activity of research makes sense. Information literacy had developed over time from a job skill to one that was more closely related to research. Meanwhile, bibliographic instruction had also shifted from the original concept-based approaches to ones that focused more on teaching students basic access skills. ${ }^{37}$ The Standards simply reflected these ways of thinking. 
The Standards was also developed at a time when academic librarians were seeking to stake a place for themselves in the missions of their institutions, which had become more closely tied to the employability of their graduates. ${ }^{38}$ For such institutions, learning outcomes became the favored way of gauging the success of a particular program. One of the Standards' stated goals is to provide measurable learning outcomes for information literacy. ${ }^{39}$ To be measurable, learning outcomes must be based on what can be observed. It is much easier to measure the development of skills than it is to measure changes in a student's worldview.

The limitations of the Standards have been well documented over time. ${ }^{40}$ One of the main shortcomings of the Standards has always been in its failure to acknowledge the importance of context to the research process. More accurately, the Standards assume a single research context: that of library-based academic research. The closest the document comes to referencing the contextual nature of research is the occasional gesture toward discipline-specific research, which is still a highly academic notion (see table 2). Despite the aspiration of the Standards toward transferability, ${ }^{41}$ research studies that have tested this idea tend to have mixed results. ${ }^{42}$

\begin{tabular}{|c|c|}
\hline \multicolumn{2}{|c|}{$\begin{array}{l}\text { TABLE } 2 \\
\text { Explicit References to Research Context and Discipline in the ACRL Standards }\end{array}$} \\
\hline Standard & Performance Indicator and Outcome \\
\hline $\begin{array}{l}\text { Standard 1: The information-literate student } \\
\text { determines the nature and extent of the } \\
\text { information needed. }\end{array}$ & $\begin{array}{l}\text { 2b: Recognizes that knowledge can be organized into } \\
\text { disciplines that influence the way information is accessed } \\
\text { 2e: Differentiates between primary and secondary sources, } \\
\text { recognizing how their use and importance vary with each } \\
\text { discipline } \\
\text { 3b: Considers the feasibility of acquiring a new language } \\
\text { or skill (such as foreign or discipline-based) to gather } \\
\text { needed information and to understand its context }\end{array}$ \\
\hline $\begin{array}{l}\text { Standard 2: The information-literate student } \\
\text { accesses needed information effectively and } \\
\text { efficiently. }\end{array}$ & $\begin{array}{l}\text { 2c: Selects controlled vocabulary specific to the discipline } \\
\text { or information retrieval source } \\
\text { 2f: Implements the search using investigative protocols } \\
\text { appropriate to the discipline }\end{array}$ \\
\hline $\begin{array}{l}\text { Standard 3: The information-literate } \\
\text { student evaluates information and its } \\
\text { sources critically and incorporates selected } \\
\text { information into his or her knowledge base } \\
\text { and value system. }\end{array}$ & $\begin{array}{l}\text { 2d: Recognizes the cultural, physical, or other context } \\
\text { within which the information was created and understands } \\
\text { the impact of context on interpreting the information } \\
\text { 4d: Tests theories with discipline-appropriate techniques } \\
\text { (examples: simulators, experiments) }\end{array}$ \\
\hline $\begin{array}{l}\text { Standard 4: The information-literate } \\
\text { student, individually or as a member of } \\
\text { a group, uses information effectively to } \\
\text { accomplish a specific purpose. }\end{array}$ & $\begin{array}{l}1 \mathrm{~d} \text { : Manipulates digital text, images, and data, as needed, } \\
\text { transferring them from their original locations and formats } \\
\text { to a new context }\end{array}$ \\
\hline $\begin{array}{l}\text { Standard 5: The information-literate student } \\
\text { understands many of the economic, } \\
\text { legal, and social issues surrounding the } \\
\text { use of information and accesses and uses } \\
\text { information ethically and legally. }\end{array}$ & No explicit reference \\
\hline
\end{tabular}


In other words, despite its stated intentions, what the document is really doing is, as Mark points out, reflecting a tendency in the academy to measure expertise by one's ability to adopt the conventions of academia. ${ }^{43}$

Because the Standards does not adequately take into account the contextual nature of research, neither does Standards-based information literacy instruction. Instead, such instruction focuses primarily if not exclusively on teaching students the basic skills associated with library-based academic research. We know this because influential tools created to standardize the assessment of information literacy learning, such as the Information Literacy VALUE rubrics and the learning goals suggested by the Middle States Commission of Higher Education, reflect it. ${ }^{44}$ We also know this because studies of syllabi for credit-bearing information literacy courses show that the most common topics taught as part of these courses are skills-based..$^{45}$

The influence of the Standards has had a noticeable effect on the way librarians think about teaching information literacy. When asked by Hofer, Townsend, and Brunetti about the most common "stuck places" students encountered when learning about research, the answers given by the librarians who participated in the study were concerned almost exclusively with academic research skills. ${ }^{46}$ One place where a more contextual view of research shows through is in the respondents' stated desire to help students better understand how the process of information creation might differ from one discipline to another.

The Standards has also had an effect on how information literacy is perceived by those outside the library field. When Gullikson asked nonlibrary faculty at what academic level they would expect students to have achieved individual learning outcomes from the Standards, the majority of those who responded indicated that they would expect students to have mastered these skills in the early part of their careers in higher education, if not before. ${ }^{47}$ Standards-based information literacy, in the eyes of nonlibrarians, is at best seen as what Norgaard calls "a mere look up skill." 48

The Standards provides no path to introducing students to the contextual nature of research. Because of this, the idea that research is both an activity and a subject of study became lost in our information literacy instruction and our thinking about information literacy instruction despite the fact that it remained a prevalent theme in our professional literature. In insisting on the importance of context to the research process, ${ }^{49}$ the Framework gives us a way to change our thinking and our instruction.

Each of the Framework's six frames is infused with implicit and explicit references to the contextual nature of research (see table 3). In fact, the only frame in which the word "context" does not appear in one form or another is "Research as Inquiry," which still manages to highlight the importance of distinguishing between processes of inquiry intended to meet different needs.

Of course, the Framework, like the Standards, is also a product of ACRL and so, as Foasberg points out, its contexts of interest are still primarily academic in nature. ${ }^{50}$ No doubt research is currently underway to test the transferability of the Framework. In the meantime, it is not difficult to imagine how the six frames could apply to nonacademic forms of research. For example, negotiating a meaning from varying perspectives, as described in the "Scholarship as Conversation" frame, is as of much concern to those conducting personal, professional, or creative research as it is to those conducting academic research. Those who follow the investigative steps of the scientific method can likely find relevance in the idea of "Research as Inquiry." 


\begin{tabular}{|c|c|}
\hline \multicolumn{2}{|c|}{$\begin{array}{l}\text { TABLE } 3 \\
\text { Explicit References to the Importance of Context in the ACRL Framework }\end{array}$} \\
\hline Frame & Relevant reference \\
\hline $\begin{array}{l}\text { Authority ls } \\
\text { Constructed and } \\
\text { Contextual }\end{array}$ & $\begin{array}{l}\text { Information resources reflect their creators' expertise and credibility, and } \\
\text { are evaluated based on the information need and the context in which the } \\
\text { information will be used. } \\
\text { [Authority] is contextual in that the information need may help to determine the } \\
\text { level of authority required. } \\
\text { An understanding of this concept enables novice learners to critically examine all } \\
\text { evidence-be it a short blog post or a peer-reviewed conference proceeding- } \\
\text { and to ask relevant questions about origins, context, and suitability for the } \\
\text { current information need. } \\
\text { Novice learners may need to rely on basic indicators of authority, such as type of } \\
\text { publication or author credentials, where experts recognize schools of thought or } \\
\text { discipline-specific paradigms. } \\
\text { [Learners who are developing their information-literate abilities] understand } \\
\text { that many disciplines have acknowledged authorities in the sense of well-known } \\
\text { scholars and publications that are widely considered "standard," and yet, even in } \\
\text { those situations, some scholars would challenge the authority of those sources. }\end{array}$ \\
\hline $\begin{array}{l}\text { Information Creation } \\
\text { as Process }\end{array}$ & $\begin{array}{l}\text { Experts recognize that information creations are valued differently in different } \\
\text { contexts, such as academia or the workplace. } \\
\text { [Learners who are developing their information-literate abilities] articulate the } \\
\text { traditional and emerging processes of information creation and dissemination in } \\
\text { a particular discipline. } \\
\text { [Learners who are developing their information-literate abilities] monitor the } \\
\text { value that is placed upon different types of information products in varying } \\
\text { contexts. }\end{array}$ \\
\hline $\begin{array}{l}\text { Information Has } \\
\text { Value }\end{array}$ & $\begin{array}{l}\text { The value of information is manifested in various contexts, including publishing } \\
\text { practices, access to information, the commodification of personal information, } \\
\text { and intellectual property laws. }\end{array}$ \\
\hline Research as Inquiry & No explicit reference \\
\hline $\begin{array}{l}\text { Scholarship as } \\
\text { Conversation }\end{array}$ & $\begin{array}{l}\text { [Learners who are developing their information-literate abilities] suspend } \\
\text { judgment on the value of a particular piece of scholarship until the larger } \\
\text { context for the scholarly conversation is better understood. }\end{array}$ \\
\hline $\begin{array}{l}\text { Searching as } \\
\text { Strategic Exploration }\end{array}$ & $\begin{array}{l}\text { Experts realize that information searching is a contextualized, complex } \\
\text { experience that affects, and is affected by, the cognitive, affective, and social } \\
\text { dimensions of the searcher. } \\
\text { [N]ovice learners tend to use few search strategies, while experts select from } \\
\text { various search strategies, depending on the sources, scope, and context of the } \\
\text { information need. }\end{array}$ \\
\hline
\end{tabular}


It may be true that not every threshold concept will apply to every research context. For some, that might be seen as a shortcoming of the present argument. However, it is worth remembering that the Framework is intended to be a flexible document, making it clear that there is room for more threshold concepts than those identified in the original version. ${ }^{51}$ Further, in establishing a set of threshold concepts related to writing studies, Adler-Kassner and Wardle and their collaborators identified 37 threshold concepts, some of which may be more applicable to the study and activity of certain genres of writing than others. Granted, this work is not intended for broad implementation the way the Framework is, but both documents are of a similar spirit. ${ }^{52}$

As stated earlier, students often enter the information literacy classroom unable to recognize that, while the skills and knowledge they have developed are valuable in some research contexts, they may be less so in others. For information literacy instructors, this has been a significant barrier, one that the Standards provided no meaningful way to overcome. The metaconcept that has been established here gives us a lens through which to understand research as not just an activity but also a subject of study. The Framework provides a path to pass on this knowledge to students by introducing them to the importance of context to the research process. The next section describes how a common model for composition instruction could be adapted for this purpose.

\section{A Suggested Model for Practical Application}

In Standards-based information literacy instruction, students are introduced to the conventions of academic research at the same time that they are expected to apply those conventions. They are expected to do this correctly without ever having seen or studied an example of such research, except perhaps one provided by their instructor for informational purposes. Badke criticizes this approach, colorfully stating, "teaching application without teaching method and philosophy is akin to showing someone how to steer and use the brakes on a car without teaching overall driving technique and the rules of the road." 53

In writing studies, there is a similar expectation that, as Sommers and Saltz put it, students will "become master builders while they are still apprentices." ${ }^{54}$ However, composition instruction does not generally begin and end with application the way information literacy instruction does. Instead, students first study a selected example of a genre of writing to learn about the conventions of that genre and then attempt to apply those conventions in their own work. Information literacy instruction could benefit from emulating this structure.

Rather than organizing an information literacy course around units based on skills, sources, or tools, the course could be organized instead around different research contexts. More work may need to be done to determine what exactly those contexts can or should be or whether the conventions, goals, and motivations of those contexts can be said to represent "genres" as the term is understood by researchers of genre theory. ${ }^{55}$ However, a general information literacy course could conceivably be organized around units on academic research, personal research, professional research, creative research, scientific research, and more.

In this approach, research skills like those described by the Standards would still be valuable but would only be taught after students first had the opportunity to study an example piece of research. Similar to the work of some professionals who study research, students could closely examine the types of sources used and think about the roles those sources play in the author's research. They might also study the way the author gives credit to those sources, per- 
haps noticing that, in some research contexts, credit is given through formal citation while in others it is done through contextual links, quotes from interview subjects, or some other way. By doing this, students would learn how the conventions of research change from context to context. They may begin to develop a more realistic view of how much more there is to learn beyond the skills they already have and why it is worth learning.

As an illustration of how a unit in a course designed like this would work, consider that in a composition course students might first be given Letter from a Birmingham Jail by Martin Luther King Jr. as an example of persuasive writing. They would study this piece before trying to emulate King's rhetorical moves in their own work.

In a unit on academic research in an information literacy course, students might first be given an example research essay or scholarly article. Rather than studying the writing, they would look at the evidence of research in the source. They might be asked to notice how the author uses citations or footnotes and includes a list of sources at the end. Attention might be drawn to the nature of the sources the author used, and critical thought might be given to why he or she made those choices. A student could also be asked to comment on how each source was used in the example piece: to add new information, to present and answer a contradicting view, to pull a quote, and so on.

The same could be done with units on other types of research. In a different unit, a personal blog post could be used as an example of personal research in which the evidence of research might appear as contextual links rather than formal citations. Or a news article could be studied as an example of journalistic or professional research in which quotes from sources with firsthand knowledge of an event are privileged over other types of sources. Even King's Letter could be used as an example of research. In this piece, King borrows ideas from and makes reference to Socrates and the Bible to support his ideas. He also relies on the authority granted to him by his own personal experience with the issues he is discussing. ${ }^{56}$

After studying the conventions of a genre of research through an example piece, students could then be taught the skills needed to complete the type of research each product represents. As a culminating project, students could be required to create a research product of their own that follows the conventions they learned about and then reflect on the ways that they used or challenged those conventions in their own work.

What is described above would be most appropriate for a general information literacy course taught at the undergraduate level. Instructors who teach more advanced or disciplinebased information literacy could adapt this approach to suit their students' needs and interests. For example, such instruction could focus more closely on the evaluation of research as it is most often represented in a field of study or profession. Students could be taught to see flaws in an author's methodology, reasoning, or use of sources. They might also benefit from reviewing studies of information behavior of relevant populations to gain an understanding of how these populations interact with and create information in various settings. Instructors could invite students to think critically about the research practices in their fields and reflect on areas of potential improvement.

\section{Caveats and Potential Concerns}

It is necessary at this point to acknowledge that the common model for teaching composition described earlier is not without its critics in that field. Connors, for example, argues that using genres and modes to teach writing is more of a convenience to the instructor than a 
reflection of how writing actually works. ${ }^{57}$ Hillocks makes the case that using genre and form to teach composition neglects the importance of inquiry and teaching students how to work with content. ${ }^{58}$

In implementing a similar model for information literacy instruction, information literacy instructors may also have concerns. Foremost among these may be a reluctance to teach research outside the discipline-agnostic academic context of past Standards-based instruction. To do so, it has been argued in the past, would be to tread on the toes of disciplinary faculty who are the rightfully recognized experts on research in their fields of study and also perhaps to stray outside our professional strengths. ${ }^{59}$ In response to this, it must be acknowledged that disciplinary faculty have been valuable partners in teaching information literacy in the past and could continue to be so in this new approach. As far as professional strengths, the Standards may have been limited to library-based academic research but the study of research in the LIS field is not, showing that contexts outside academia are, in fact, within our professional domain. Even if they were not, librarians tend to portray themselves as research experts as a way of communicating their value to their institutions. Taking advantage of the ways in which researchers in our own field have cultivated an understanding of how research works in a variety of contexts can only enhance our ability to label ourselves this way.

Another possible area of concern might be one anticipated by Townsend, Brunetti, and Hofer who acknowledge that threshold concepts like the ones found in the Framework tend to privilege certain ways of thinking. ${ }^{60}$ Information literacy instructors may feel that the study of research is for professionals only and that teaching it to students would set up an expectation that, to be successful researchers, they need to become junior librarians or junior professors. However, it is worth noting that the goal of composition instruction, which involves both the study and practice of writing, is to teach students to be competent writers with an appreciation for rhetorical context. They are introduced to expert ways of thinking as a way of expanding their worldview but are not expected to become published (or even publishable) authors as a result of what they learn.

Finally, there may be some question of whether teaching students the conventions associated with different research contexts and then expecting them to follow those conventions stifles creativity by inviting conformity to existing systems. In answer to this, it could be argued that using the conventions of research as a teaching tool opens the door to conversations about why those conventions exist in the first place and in what ways they uphold what Beilin refers to as the "knowledge regime." ${ }^{61}$ Teaching students to think critically about the research that goes into creating a particular research product would enable them to more clearly see how the recontextualization process that is part of all research is subject to the inherent biases and worldviews of the author. ${ }^{62}$ Even more important, as observed by Simmons, when students learn about generic conventions, they may learn to see themselves as having "the potential to effect changes in the conventions instead of simply learning to conform to the established patterns." ${ }^{\prime 63}$ In other words, learning "the rules" is also the first step in learning how to break those rules and challenge the systems that created them in meaningful and interesting ways.

\section{Conclusion}

Current models of information literacy instruction that treat research as nothing more than a basic skill do not serve students well. They also do not serve information literacy well. Research is not a basic skill that can be mastered for a lifetime in the space of a single instruction 
session. It is an activity that relies heavily on rhetorical context. It is also a subject of study with areas of inquiry in which context is often a large consideration. To paraphrase Wardle and Adler-Kassner, ${ }^{64}$ a successful researcher is someone who cultivates an understanding of the expectations associated with research in a given context and then meaningfully engages with those expectations. Such a researcher is both a consumer and a creator of information.

The metaconcept introduced in this article, that research is both an activity and a subject of study, is an attempt to name something that has been present in LIS literature all along but for which there has been no room in information literacy instruction in the past. Future work to identify the ways in which this metaconcept has manifested itself in the literature in our field will be valuable in helping us to articulate the value of our work in a new way. In the meantime, it could serve as a useful frame for transforming information literacy instruction and enhancing the reputation of information literacy as something more than a basic skill.

\section{Notes}

1. Valeria E. Molteni and Emily K. Chan, "Student Confidence/Overconfidence in the Research Process," Journal of Academic Librarianship 41, no. 1 (2015): 2-8.

2. Nancy Sommers and Laura Saltz, "The Novice as Expert: Writing the Freshman Year," College Composition and Communication 56, no. 1 (2004): 124-49.

3. Elizabeth Wardle and Linda Adler-Kassner, "Metaconcept: Writing Is an Activity and a Subject of Study," in Naming What We Know: Threshold Concepts of Writing Studies, eds. Linda Adler-Kassner and Elizabeth Wardle (Boulder: University Press of Colorado, 2015), 15-16.

4. Office for Human Research Protection, "Basic HHS Policy for Protection of Human Research Subjects" (2009), available online at https://www.hhs.gov/ohrp/regulations-and-policy/regulations/45-cfr-46/index.html [accessed 23 January 2018].

5. ACRL Information Literacy Competency Standards for Higher Education, "Information Literacy Defined" (2000), available online at www.ala.org/acrl/standards/informationliteracycompetency [accessed 23 January 2018].

6. ACRL Framework for Information Literacy for Higher Education, "Introduction" (2015), available online at www.ala.org/acrl/standards/ilframework [accessed 23 January 2018].

7. T.D. Wilson, “Models in Information Behaviour Research," Journal of Documentation 55, no. 3 (1999): 251.

8. Judith M. Nixon, "Core Journals in Library and Information Science: Developing a Methodology for Ranking LIS Journals," College E Research Libraries 75, no. 1 (2014): 66-90.

9. Examples include: Stephen E. Atkins, "Subject Trends in Library and Information Science Research, 1975-1984," Library Trends 36, no. 4 (Spring 1988): 633-58; Lois Buttlar, "Analyzing the Library Periodical Literature: Content and Authorship," College \& Research Libraries 52, no. 1 (Jan. 1991): 38-53; Gloria S. Cline, "College $\mathcal{E}$ Research Libraries: Its First Forty Years," College \& Research Libraries 43, no. 3 (1982): 208-32; Gregory A. Crawford, "The Research Literature of Academic Librarianship: A Comparison of College \& Research Libraries and Journal of Academic Librarianship," College \& Research Libraries 60, no. 3 (1999): 224-30; Amy VanScoy and Cady Fontana, "How Reference and Information Services is Studied: Research Approaches and Methods," Library \& Information Science Research 38, no. 2 (2016): 94-100.

10. Otto Tuomaala, Kalervo Jarvelin, and Pertti Vakkari, "Evolution of Library and Information Science, 1965-2005: Content Analysis of Journal Articles," Journal of the Association for Information Science E Technology 65, no. 7 (2014): 1446-62.

11. Steven Buchanan and Lauren Tuckerman, "The Information Behaviours of Disadvantaged and Disengaged Adolescents," Journal of Documentation 72, no. 3 (2016): 527-48; Jacob Dankasa, "Mapping the Everyday Life Information Needs of Catholic Clergy: Savolainen's ELIS Model Revisited," Journal of Documentation 72, no. 3 (2016): 549-68; Maja Krtalic, Sanjica Faletar Tanackovic, and Damir Hasenay, “Linguists as Newspaper Users: Perceptions and Experiences," Library and Information Science Research 38, no. 2 (2016): 108-16; Grace Msoffe and Patrick Ngulube, "Farmers' Access to Poultry Management Information in Selected Areas of Tanzania," Library and Information Science Research 38, no. 3 (2016): 82-90.

12. Examples include: Nancy Falciani-White, “Understanding the 'Complexity of Experience': Modeling Faculty Research Practices," Journal of Academic Librarianship 42, no. 2 (2016): 118-26; Christopher V. Hollister, "An Exploratory Study on Post-tenure Research Productivity Among Academic Librarians," Journal of Academic 
Librarianship 42, no. 4 (2016): 368-81; Sloan Komissarov and James Murray, "Factors That Influence Undergraduate Information-seeking Behavior and Opportunities for Student Success," Journal of Academic Librarianship 42, no. 4 (2016): 423-49; Carol Sabbar and Iris Xie, "Language in the Information-Seeking Context: A Study of U.S. Scholars Using Non-English Sources," Journal of Documentation 72, no. 1 (2016): 103-26.

13. Examples include: Lisa M. Given et al., “Watching Young Children 'Play' with Information Technology: Everyday Life Information Seeking in the Home," Library and Information Science Research 38, no. 4 (2016): 344-52; Helena Känsäkoski and Maija-Leena Huotari, "Applying the Theory of Information Worlds Within a Health Care Practise in Finland," Journal of Documentation 72, no. 2 (2016): 321-41; Reijo Savolainen, "Approaches to Socio-Cultural Barriers to Information Seeking," Library and Information Science Research 38, no. 1 (2016): 52-59.

14. Examples include: Elham Sayyad Abdi, Helen Partridge, and Christine Bruce, "Web Designers and Developers' Experience of Information Literacy: A Phenomenographic Study," Library and Information Science Research 38, no. 4 (2016): 353-59; Rebecca Lea French and Kirsty Williamson, "The Information Practices of Welfare Workers: Conceptualizing and Modelling Information Bricolage," Journal of Documentation 72, no. 4 (2016): 737-54; Ayse Göker et al., "Expeditions Through Image Jungles: The Commercial Use of Image Libraries in an Online Environment," Journal of Documentation 72, no. 1 (2016): 5-23.

15. Examples related to each theme mentioned include: Nicolas Robinson-Garcia, Evaristo Jimenez-Contreras, and Daniel Torres-Salinas, "Analyzing Data Practices Using the Data Citation Index," Journal of the Association for Information Science \& Technology 67, no. 12 (2016): 2964-75; Angela Dresselhaus, "Literature of Acquisitions in Review, 2012-2013," Library Resources \& Technical Services 60, no. 3 (2016): 169-81; and Dian Walster, Deborah H. Charbonneau, and Kafi Kumasi, "Finding and Reading Reports of Research: How Academic Librarians Can Help Students Be More Successful," Journal of Academic Librarianship 42, no. 6 (2016): 732-38.

16. Examples include: Cheryl D. Bain et al., "Using WorldShare Collection Evaluation to Analyze Physical Science and Engineering Monograph Holdings by Discipline," Collection Management 41, no. 3 (2016): 133-51; Michael Hughes, "A Long-Term Study of Collection Use Based on Detailed Library of Congress Classification, a Statistical Tool for Collection Management Decisions," Collection Management 41, no. 3 (2016): 152-67; Blanca Rodriguez-Bravo and Francisco Rodriguez-Sedano, "Trends in Library Collection Circulation in Spanish Universities," Library Resources \& Technical Services 60, no. 4 (2016): 248-58.

17. Examples include: Kelsey Renee Brett, Ashley Lierman, and Cherie Turner, "Lessons Learned: A Primo Usability Study," Information Technology and Libraries 35, no. 1 (2016): 7-25; Reese Hoi Yin Fung, Dickson K.W. Chiu, Eddie H.T. Ko, Kevin K.W. Ho, and Patrick Lo, "Heuristic Usability Evaluation of University of Hong Kong Libraries' Mobile Website," Journal of Academic Librarianship 42, no. 5 (2016): 581-94; Joanne Oud, "Accessibility of Vendor-Created Database Tutorials for People with Disabilities," Information Technology and Libraries 35, no. 4 (2016): 7-18; Kyunghye Yoon et al., "An Exploratory Study of Library Website Accessibility for Visually Impaired Users," Library \& Information Science Research 38, no. 3 (2016): 250-58.

18. Examples include: Çağrı Imamoğlu and Meltem Ö. Gürel, “'Good Fences Make Good Neighbors': Territorial Dividers Increase User Satisfaction and Efficiency in Library Study Spaces," Journal of Academic Librarianship 42, no. 1 (2016): 65-73; Vera Lux, Robert J. Snyder, and Colleen Boff, "Why Users Come to the Library: A Case Study of Library and Non-Library Units," Journal of Academic Librarianship 42, no. 2 (2016): 109-17; Silas M. Oliveira, "Space Preferences at James White Library: What Students Really Want," Journal of Academic Librarianship 42, no. 4 (2016): 355-67.

19. Examples include: Edward Kai Fung Dang, Robert W.P. Luk, and James Allan, "A Context-Dependent Relevance Model," Journal of the Association for Information Science E Technology 67, no. 3 (2016): 582-93; Bo Xu, Hongfei Lin, and Yuan Lin, "Assessment of Learning to Rank Methods for Query Expansion," Journal of the Association for Information Science \& Technology 67, no. 6 (2016): 1345-57.

20. Gloria J. Leckie, (1996). “Desperately Seeking Citations: Uncovering Faculty Assumptions About the Undergraduate Research Process," Journal of Academic Librarianship 22, no. 3 (1996): 201-08.

21. Claire Warwick et al., "Cognitive Economy and Satisficing in Information Seeking: A Longitudinal Study of Undergraduate Information Behavior," Journal of the American Society for Information Science E Technology 60, no. 12 (2009): 2402-15.

22. James P. Purdy, "Why First-Year College Students Select Online Research Resources as Their Favorite," First Monday 17, no. 9 (2012).

23. Kyung-Sun Kim and Sei-Ching Joanna Sin, "Selecting Quality Sources: Bridging the Gap Between the Perception and Use of Information Sources," Journal of Information Science 37, no. 2 (2011): 178-88.

24. Allison J. Head, Michele Van Hoeck, Jordan Eschler, and Sean Fullerton, "What Information Competencies Matter in Today's Workplace?" Library and Information Research 37, no. 114 (2013): 75-104.

25. Barbara Fister, "Teaching the Rhetorical Dimensions of Research," Research Strategies 11, no. 4 (1993): 211-19.

26. Jeanne R. Davidson and Carole Anne Crateau. "Intersections: Teaching Research Through a Rhetorical 
Lens," Research Strategies 16, no. 4 (1998): 245-57.

27. Michelle Holschuh Simmons, "Librarians as Disciplinary Discourse Mediators: Using Genre Theory to Move toward Critical Information Literacy," portal: Libraries and the Academy 5, no. 3 (2005): 297-311.

28. Benjamin R. Harris, "Communities as Necessity in Information Literacy Development: Challenging the Standards," Journal of Academic Librarianship 34, no. 3 (2008): 250.

29. Allison Faix, "Assisting Students to Identify Sources: An Investigation," Library Review 53, no. 8/9 (2014): 624-36.

30. Doug Brent, "Crossing Boundaries: Co-Op Students Relearning to Write," College Composition and Communication 63, no. 4 (2012): 558-92; Sarah North, "Different Values, Different Skills? A Comparison of Essay Writing by Students from Arts and Science Backgrounds," Studies in Higher Education 30, no. 5 (2005): 517-33.

31. Jens B. Asendorpf et al., "Recommendations for Increasing Replicability in Psychology," European Journal of Personality 27, no. 2 (2013): 108-19.

32. Examples include: Shane W. Bench et al., "Does Expertise Matter in Replication? An Examination of the Reproducibility Project: Psychology," Journal of Experimental Social Psychology 68 (2017): 181-84; and Alexander Etz and Joachim Vandekerckhove, "A Bayesian Perspective on the Reproducibility Project: Psychology," Plos One 11, no. 2 (2016): 1-12.

33. Wolfgang Stroebe, "Are Most Published Social Psychological Findings False?" Journal of Experimental Social Psychology 66 (2016): 134-44.

34. Examples include: Mark J. Brandt et al., "The Replication Recipe: What Makes for a Convincing Replication?" Journal of Experimental Social Psychology 50 (2014): 217-24; and Sean Grant, Lukasz Cybulski, and Evan Mayo-Wilson, "Improving Transparency and Reproducibility through Registration: The Status of Intervention Trials Published in Clinical Psychology Journals," Journal of Consulting and Clinical Psychology 84, no. 9 (2016): 753-67.

35. Uri Simonsohn, "Small Telescopes: Detectability and the Evaluation of Replication Results," Psychological Science 26, no. 5 (2015): 559-69.

36. Timothy M. Errington et al., "Science Forum: An Open Investigation of the Reproducibility of Cancer Biology Research," eLife 3 (2014).

37. Shirley J. Behrens, "A Conceptual Analysis and Historical Overview of Information Literacy," College $\mathcal{E}$ Research Libraries 55, no. 4 (1994): 309-22; Frances L. Hopkins, "A Century of Bibliographyic Instruction: The Historical Claim to Professional and Academic Legitimacy," College \& Research Libraries 43, no. 3 (1982): 192-98; Mary F. Salony, "The History of Bibliographic Instruction: Changing Trends From Books to the Electronic World," Reference Librarian 24, no. 51 (1995): 31-51.

38. Emily Drabinski, "Toward a Kairos of Library Instruction," Journal of Academic Librarianship 40, no. 5 (2014): 480-85; Heidi L.M. Jacobs, "Information Literacy and Reflective Pedagogical Praxis," Journal of Academic Librarianship 34, no. 3 (2008): 256-62.

39. ACRL Standards, "Information Literacy and Assessment."

40. Notable examples of such thinking include: James Elmborg, "Critical Information Literacy: Implications for Instructional Practice," Journal of Academic Librarianship 32, no. 2 (2006): 192-99; Edward K. Owusu-Ansah, "Information Literacy and the Academic Library: A Critical Look at a Concept and the Controversies Surrounding It," Journal of Academic Librarianship 29, no. 4 (2003): 219-30; Troy A. Swanson, "Applying a Critical Pedagogical Perspective to Information Literacy Standards," Community \& Junior College Libraries 12, no. 4 (2004): 65-78: Eamon Tewell, "A Decade of Critical Information Literacy: A Review of the Literature," Communications in Information Literacy 9, no. 1 (2015): 24-43.

41. ACRL Standards, "Information Literacy Defined"; ACRL Standards, "Information Literacy and Higher Education."

42. Examples include: Brent, "Crossing Boundaries"; Jason Eyre, "Context and Learning: The Value and Limits of Library-Based Information Literacy Teaching," Health Information and Libraries Journal 29, no. 4 (2012): 344-48; and Kaye Towlson and Nathan Rush, "Carving the Information Literacy Niche Within Graduate Employability," New Review of Academic Librarianship 19, no. 3 (2013): 300-15.

43. Amy E. Mark, "Privileging Peer Review: Implications for Undergraduates," Communications in Information Literacy 5, no. 1 (2011): 4-8.

44. Association of American Colleges \& Universities, "Information Literacy VALUE Rubric" (2010), available online at https://www.aacu.org/value/rubrics/information-literacy [accessed 23 January 2018]; Middle States Association of Colleges and Schools Commission on Higher Education, Developing Research E Communication Skills: Guidelines for Information Literacy Instruction (Philadelphia: Middle States Commission on Higher Education, 2003).

45. Paul L. Hrycaj, "An Analysis of Online Syllabi for Credit-Bearing Library Skills Courses," College E Research 
Libraries 67, no. 6 (2006): 525-35; Rachael E. Elrod, Elise D. Wallace, and Cecilia B. Sirigos, “Teaching Information Literacy: A Review of 100 Syllabi," Southeastern Librarian 60, no. 3 (2012): 8-15.

46. Amy R. Hofer, Lori Townsend, and Korey Brunetti, "Troublesome Concepts and Information Literacy: Investigating Threshold Concepts for IL Instruction," portal: Libraries and the Academy 12, no. 4 (2012): 387-405.

47. Shelley Gullikson, "Faculty Perceptions of ACRL's Information Literacy Competency Standards for Higher Education," Journal of Academic Librarianship 32, no. 6 (2006): 583-92.

48. Rolf Norgaard, "Writing Information Literacy: Contributions to a Concept," Reference \& User Services Quarterly 43, no. 2 (2003): 126.

49. ACRL Framework, "Introduction."

50. Nancy M. Foasberg, "From Standards to Frameworks for IL: How the ACRL Framework Addresses Critiques of the Standards," portal: Libraries and the Academy 15, no. 4 (2015): 708.

51. ACRL Framework, "Introduction."

52. Elizabeth Wardle and Linda Adler-Kassner, "Naming What We Know: The Project of This Book," in Naming What We Know: Threshold Concepts of Writing Studies, eds. Linda Adler-Kassner and Elizabeth Wardle (Boulder: University Press of Colorado, 2015), 8.

53. William Badke, "A Rationale for Information Literacy as a Credit-Bearing Discipline," Journal of Information Literacy 2, no. 1 (2008).

54. Sommers and Saltz, "The Novice as Expert," 132.

55. Amy J. Devitt, Writing Genres (Carbondale: Southern Illinois University Press, 2004).

56. Martin Luther King, Jr., Letter from a Birmingham Jail, available online at https://kinginstitute.stanford.edu/ king-papers/documents/letter-birmingham-jail [accessed 23 January 2018].

57. Robert J. Connors, "The Rise and Fall of the Modes of Discourse," College Composition and Communication 32, no. 4 (1981): 444-55.

58. George Hillocks, Jr., "The Focus on Form vs. Content in Teaching Writing," Research in the Teaching of English 40, no. 2 (2005): 238-48.

59. Richard Feinberg and Christine King, "Short-Term Library Skill Competencies: Arguing for the Achievable," College E Research Libraries 49, no. 1 (1988): 24-28.

60. Lori Townsend, Korey Brunetti, and Amy R. Hofer, "Threshold Concepts and Information Literacy," portal: Libraries and the Academy 11, no. 3 (2011): 853-69.

61. Ian Beilin, "Beyond the Threshold: Conformity, Resistance, and the ACRL Information Literacy Framework for Higher Education," In the Library with the Lead Pipe (Feb. 25, 2015), available online at www.inthelibrarywiththeleadpipe.org/2015/beyond-the-threshold-conformity-resistance-and-the-aclr-information-literacy-frameworkfor-higher-education/ [accessed 26 October 2018].

62. Christine Pawley, "Information Literacy: A Contradictory Coupling," Library Quarterly 73, no. 4 (2003): $422-52$.

63. Simmons, "Librarians as Disciplinary Discourse Mediators," 302.

64. Wardle and Adler-Kassner, "Metaconcept," 16. 